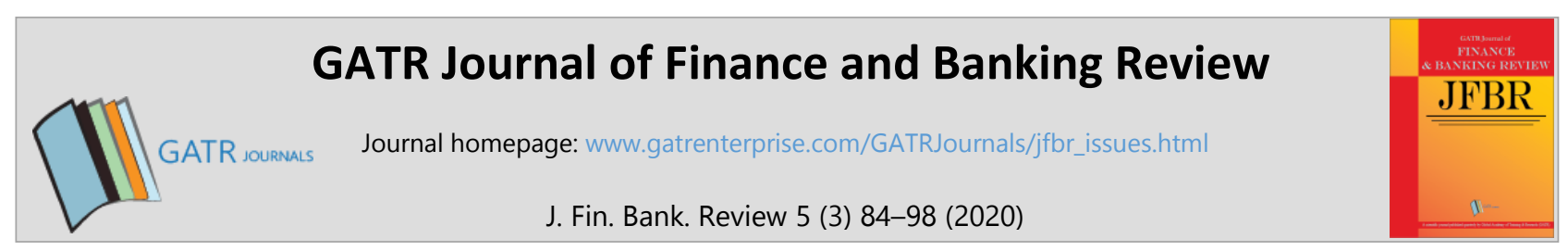

\title{
Tax Policy and Foreign Direct Investment: A Regime Change Analysis.
}

\author{
Onome Christopher Edo*1, Anthony Okafor, PhD. ${ }^{2}$, Akhigbodemhe Emmanuel Justice ${ }^{3}$ \\ ${ }^{1}$ Department of Accounting, University of Benin, Nigeria. \\ ${ }^{2}$ Department of Finance, University of Louisville, Kentucky \\ ${ }^{3}$ Department of Economics, University of Benin, Nigeria
}

\begin{abstract}
Objective - Tax policies play significant role in the direction of foreign direct investments. We investigate the proposition that tax policies enacted by military and democratic regimes differ on the influence the foreign direct investments.

Methodology/Technique - Our hypotheses are tested using the error correction model as we compare the impact of tax policies on flow foreign direct investments in Nigeria between two dispensations: military rule from 1983 to 1999 and democratic rule from 1999 to 2017. Panel data between 1983 and 2017 were obtained from the databases of the World Bank, Central Bank of Nigeria and the Federal Inland Revenue Services. The explanatory variables include company income tax, value added tax, tertiary education tax and customs and exercise duties.

Findings - The study revealed that tax variables during the military regime exerted more explanatory power of $79 \%$ compared to the civilian administration of $66 \%$ with respect to the impact of corporate taxes on FDI. The effect of company income tax on FDI was more pronounced during the military regime than in the civilian regime. FDI had a higher degree of convergence during the military regime compared to civilian rule, and this is vital for policy assessments.
\end{abstract}

Novelty - This research is a departure from prior studies, as we bring to light new evidences on the effects of taxes polices on FDI.

Type of Paper: Empirical

Keywords: Corporate taxes; Tax Policies; Foreign Direct Investments; Error Correction Model; Military regime; Civilian regime.

Reference to this paper should be made as follows: Edo, O.C; Okafor, A; Emmanuel, A. (2020). Tax Policy and Foreign Direct Investment: A Regime Change Analysis., J. Fin. Bank. Review, 5 (3): 84 - 98 https://doi.org/10.35609/jfbr.2020.5.3(3)

JEL Classification: E22, F21, H2, P33.

\section{Introduction}

Globalization has led to an unprecedented flow in foreign direct investments since the turn of the 21st century. The concept of foreign direct investment (FDI) has become a global phenomenon among developed and developing economies, specifically in the last decade.

\footnotetext{
* Paper Info: Revised: October 24, 2020

Accepted: December 31, 2020

* Corresponding author: Onome Christopher Edo

E-mail: chrisovik@gmail.com

Affiliation: Department of Accounting, University of Benin, Nigeria.
} 
Governments have taken a more nuanced approach towards attracting FDI to their countries to address developmental gaps, increase employment opportunities, and close investment gaps (Sabir \& Khan, 2018). Others have done this to enhance human capital development, technology advancement, and foreign exchange stability (Chenaf-Nicet \& Rougier, 2016). Organizations have also adopted the foreign direct investment concept as means to access new markets and to facilitate participation in global value chains needed to strengthen local firms and their subsidiaries (Dinh et al., 2019; Erhieyovwe \& Eshanake, 2016; United Nations, 2019).

The flow of foreign direct investments in Africa has been a significant enabler for development and has complemented various governments' efforts towards achieving the 2030 Agenda for Sustainable Goals (SDGs). To reach these goals, we assess the impact of varying factors on the flow of FDI in Nigeria. The pattern of FDI flow to Nigeria in recent times has been abysmal, and the trend has been erratic with a mixture of inflows and outflows, especially to neighboring African countries. For instance, between 1994 and 2018, over 232 textile firms shut down and relocated to other countries and in 2009 alone, approximately 820 manufacturing companies closed their factories in Nigeria and relocated to other countries (Frankilin, 2009). Also, between 2015 and 2017, over 195 manufacturing firms, including top multinational companies, exited the country to other neighboring countries (Babatope, 2020).

Beyond the profit motive, investors consider other factors when making investment decisions and choice of location. Notable among these are country diplomacy, political stability, the legal system's efficacy, and political disposition and dispensation (Abbas, 2019; Daniel \& Thomas, 2018; Li, Owen, \& Mitchell, 2016; Schoeman, 2015). Other documented factors include trade openness, inflation, tax policy, and host government attitude to investors (Raudonen, 2016; Akinwunmi, Olotu \& Adegbie, 2017; Eiya \& Okaiwele, 2019). Investors believe that earnings might be eroded if these factors are not evaluated before decisions on the location of investments are made.

Nigeria was plagued with political instability since her independence in 1960 and only fully returned to civil rule in 1999. However, from 1960 to date, Nigeria has witnessed 15 successive governments from 1960 to date; eight of these were under military control, with little or no regard for the rule of law and sanctity of contracts, frequent policy changes, and lack of continuity. Frequent changes in administration, especially those orchestrated by the military, have come with untoward consequences leading to the abdication of the rule of law, weakening institutions, and the usurpation of power by nondemocratic regimes (Goldstone et al., 2010).

Military dictatorship and political instability have always been a major concern for foreign investors (Daniel \& Thomas, 2018; Schoeman, 2015). Conversely, FDIs are attracted to open economies with enhanced property rights, political stability, growth-enhancing policies, active media, and labor-oriented policies, which are typical of economies managed by democratically run governments because they reduce economic uncertainty ( $\mathrm{Li}$, Owen, \& Mitchell, 2016). Therefore, regime type has implications for how an economy is able to compete for FDI. Competing for limited FDI flows has been a long-standing issue. Oates (1972) observed that governments have resorted to tax reduction as a strategy to encourage the inflow of capital and investments, and an adjustment in fiscal policy could swing the balance in the flow of FDI. Thus, this reinforces the arguments for special tax preferences for foreign investors as a motivating factor to mitigate the cost of other discouraging variables such as political instability, insecurity, and infrastructural challenges.

The debate on the effect of taxes and other incentives on the flow of FDI have continued to generate the attention of scholars as well as fiscal authorities. Studies conducted in this regard have yielded mixed results. The impact of regime changes on the flow of FDIs in Nigeria has not received worthwhile attention. In our estimation, only three studies have come close. These studies evaluated the impact of regime change on FDI in Nigeria (Anyiwe \& Aigbokhaevbolo, 2006; Ebekozien, Abdul-Aziz, \& Jaafar, 2018; Kolawole, Lucky \& Ekemini, 2018). The gap in existing literature remains because researchers have yet to examine the aggregate impact of both regimes' tax policies on the flow of FDI in the country. 
In our attempt to bridge this gap, we juxtapose the impact of tax policies on FDI flows in Nigeria between two dispensations, military rule from 1983 to 1999 and democratic rule from 1999 to 2017. Specifically, we probe the impact of Company income tax, value-added tax, customs and excise duties, education tax and non-tax variables on the FDI flows in the two regimes from 1983 to 2017 considering, the military interregnum from 1983 to 1999 and the return to the democratic regime from 1999 to 2017. This study attempts to expand extant literature by unearthing the impact of political systems on the flow of FDI in Nigeria, taking into account the fiscal policies of the military and the civilian administration.

The remainder of the paper is divided into three sections. Section 2 contains the literature review, part 3 is the presentation of the data and methodology adopted, and section 4 discusses results, while section 5 concludes the paper.

\section{Literature Review}

The debate over the use of taxation as an incentive has continued. Taxation is both an enabler for economic growth and a prime source of government revenue. Proponents of tax reduction have argued that reducing taxes could incentivize foreign investment decisions as well as stimulate growth in the economy (Adegbite \& Shittu, 2017; Boly, Coulibaly, \& Kere, 2020; Eiya \& Okaiwele, 2019; Gideon, Odunayo \&, Samson 2019; Van, 2019). Critics, who are opposed to this concept, believe that tax cuts negate the ability to achieve growth as this is not a principal factor for foreign investment decisions and that this policy hurts government revenue and by extension the economy at large (OECD, 2015; World Bank,2015).

Researches have been conducted to examine the predominant variables responsible for attracting FDI; notable among these are the pioneering works of (Tiebout, 1956; Oates, 1972; Zodrow \& Mieszkowski, 1986, Dunning, 1993). Thenceforward, emerging contribution to the literature on the determinants of FDI have considered Market size (GDP), Natural resources, Openness, Inflation rate, Exchange rate, Interest rate, Infrastructure, Fiscal deficit, Debt ratio, Size (Ratio of government consumption to GDP), Political stability, Electricity consumption, corporate tax, Transportation and communication, Telephone lines availability, Labour cost and Human capital as variables (Anyanwu, \& Yameogo, 2015; Arawomo \& Apanisile, 2018; Eiya \& Okaiwele, 2019; Ojong, Arikpo \& Ogar, 2015).

The association between corporate taxes and FDI in Nigeria was investigated by Saidu (2015) after obtaining data from 1970 through 2013 using correlation and regression analysis. The result reveals a negative but significant relationship between corporate tax and FDI. Likewise, Akinwunmi, Olotu, and Adegbie (2017) examine the impact of multiple taxes and FDI in Nigeria from 1996 through 2005. Using multiple regression estimation technique, the study finds a strong but negative relationship between company taxes and FDI and concludes that higher taxes deter foreign direct investments. This study agrees with that of (Saidu, 2015). These studies are similar to those of Sheedy, Zhang, \& Tam (2017). They found no relationship between corporate taxes and FDI, and that of Eiya and Okaiwele (2019) where they found no significant connection with petroleum profit tax, custom and excise duties and FDI.

Olaleye, Riro and Memba (2016) study the connection between reduced company income taxes incentives and FDI in the Nigerian manufacturing sector using correlation statistics and regression analysis. After administering 352 questionnaires from a sample of 32 manufacturing companies, the study finds strong evidence of a positive linear relationship between reduced company income tax incentives and foreign direct investment. Applying the auto distributed lag (ADRL) regression technique, Eiya and Okaiwele (2019) examined the relationship between varying forms of taxes and foreign direct investment in Nigeria from 1982 through 2015. The study concluded that value-added tax and company income tax had a significant impact on FDI flows. The study, however, finds no effect of customs and excise duties and petroleum profit tax on the flow of FDI.

Further, Etim, Jeremiah, and Jeremiah (2019) investigate the link between FDI and tax policies in Nigeria from 1999 -2017. The study sought to ascertain the effectiveness of cost-based and profit-based tax incentives in attracting FDI. Using multiple regressions to analyze the research data, they find a strong 
association between cost-based tax policy and FDI. They found no connection between profit-based tax policy and FDI. The study recommended the use of non-tax incentives to attract FDI. The institutional quality of a host country also determines the level of commitment of investors. North (1990) identified institutional quality reduces the cost of doing business, including a reduction in transaction, manufacturing, and production with a potential impact on profitability. Property rights, contract enforcement, political and economic stability are suitable institutional factors that foreign investors seek when making investment decisions and withdraw from economies where these conditions are eroded or nonexistent.

Investors seek long term sustainability of their businesses and, as such, are likely to invest in economies noted for promoting democratic rights and locations where legal contracts are not easily rescinded. Once these cannot be guaranteed, investors tend to move their investments to locations that satisfy their legal and business concerns, whether in a democratic dispensation. Extant literature is replete with studies on the various factors influencing the direction of FDI. However, from Nigeria's perspective and based on our findings, we are yet to find studies investigating the aggregate effect of taxes and political regimes on FDI flow.

For instance, Kolawole, Lucky, and Ekemini (2018) examine the factors responsible for the flow of foreign direct investments in Nigeria using an Error Correction Mechanism between 1986 and 2007. Specifically, the study investigates the determinants of FDI flows to Nigeria. The predictive variables include GDP, exchange rate, interest rate, inflation rate, trade openness, government expenditure, financial development, and political stability. The study finds that exchange rate, GDP, government expenditure, political stability, and financial development are the major determinants of FDI flows to Nigeria. Specifically, the result reveals the positive linkage between the democratic regime and FDI flows, averring that Nigeria witnessed more FDI flows during the democratic dispensation. While this study reveals this relationship, the study differs from ours as it does not account for tax variables. Moreover, our study extends the democratic rule by ten years which is a good fit for a study of this nature.

Likewise, Ebekozien, Abdul-Aziz, and Jaafar (2018) conducted a comparative study of foreign direct investments in Nigeria's construction sector during the military regime and democratic government by investigating the inflow of FDI to the construction sector from 1984 to 2017. The study reveals that the military style of government hampered the flow of FDI to Nigeria during the military regime and recommended a sustained democracy for the flow of FDI. However, the study is limited as it only accounts for the flow of FDI in the construction industry, and more so differs from our study since it does not acknowledge the impact of taxes in the study.

Outside Africa, studies have also focused on establishing a possible relationship between the two variables. In Europe, Raudonen (2016) investigates the effects of corporate taxes and FDI in the E.U. using general linearized equation and gravity approach to analyze a panel data from 23 countries covering a period of 1998-2011. Raudonen (2016) utilized corporate tax rate, market size, level of unemployment, infrastructure, and double taxation treaties as explanatory variables. Raudonen (2016) concludes that FDI flows targeted at manufacturing services are sensitive to corporate tax rate, noting that a $1.0 \%$ decrease in corporate tax rate increases FDI by $0.02 \%$ in the E.U. Similarly, Davies, Siedschlag and Studnicka (2017) investigate the effect of corporate taxation on FDI between 2002 and 2013 using a nested logit model (NLM). The study finds an association between reduced corporate taxes and FDI in the services sector. However, they found no connection between taxes and FDI in the manufacturing industry.

In other to bridge the existing gap in the literature, the overarching objective of this study is to determine the impact of tax policies on FDI between two dispensations, military rule from 1983 to 1999, and democratic rule from 1999 to 2017. Drawing from the tax competition theory by Oates (1927) and the institutional theory by North (1990), we examine the impact of Company income tax, value-added tax, customs and excise duties, education tax and non-tax variables on the FDI flows in the two regimes from 1983 to 2017 considering, the military interregnum from 1983 to 1999 and the return to the democratic administration from 1999 to 2017 . The following hypotheses guide this study: 
H1: Company income tax has no significant impact on FDI in a Military and civilian regime.

$\mathrm{H}$ 2: Value added tax has no significant impact on FDI in a Military and Civilian regime.

H3: Tertiary education tax has no significant impact on FDI in a Military and Civilian Regime.

H4: Customs and Excise have no significant impact on FDI in a Military and Civilian regime.

\section{Data and Methodology}

We adopt FDI net inflows as our dependent variable from 1983 through 2017 using data obtained from the World Bank development indicators. The independent variables used in the study include Company income tax; value-added tax, customs and excise duties, education tax. Inflation, trade openness, market size, exchange rate and GDP growth rate are the non-tax explanatory variables used in the study. Research data for company income tax, value-added tax and tertiary education tax were sourced from the World Bank development indicator and the Federal Inland Revenue Service database, while the data for customs and excise duties were sourced from the database of the Central Bank of Nigeria (CBN). The non-tax variables; inflation, trade openness, market size, exchange rate and GDP growth rate were sourced from the World Bank development indicators and corroborated with data obtained from Nigerian Bureau of Statistics (NBS)

Table I. Definition of variables

\begin{tabular}{|c|c|c|c|c|c|}
\hline S/No. & Variables & Proxy & Measurement & Sources & $\begin{array}{l}\text { Apriori } \\
\text { sign }\end{array}$ \\
\hline 1. & $\begin{array}{l}\text { Foreign Direct } \\
\text { Investment } \\
\text { (Dependent } \\
\text { Variable) }\end{array}$ & FDI & Annual FDI inflow & $\begin{array}{c}\text { World Bank development } \\
\text { indicator, Nigerian stock } \\
\text { exchange manual, }\end{array}$ & Nil \\
\hline 2. & $\begin{array}{c}\text { Company Income } \\
\text { Tax } \\
\text { (Independent } \\
\text { Variable) }\end{array}$ & CIT & $\begin{array}{l}\text { Annual company income tax } \\
\text { value }\end{array}$ & $\begin{array}{l}\text { CBN Statistical bulletin, } \\
\text { FIRS, }\end{array}$ & - \\
\hline 3. & $\begin{array}{l}\text { Value Added Tax } \\
\text { (Independent } \\
\text { Variable) }\end{array}$ & VAT & $\begin{array}{c}\text { Annual VAT value paid by } \\
\text { operating entities }\end{array}$ & $\begin{array}{c}\text { CBN Statistical bulletin, } \\
\text { FIRS, }\end{array}$ & - \\
\hline 4. & $\begin{array}{c}\text { Tertiary Education } \\
\text { Tax } \\
\text { (Independent } \\
\text { Variable) }\end{array}$ & TET & $\begin{array}{c}\text { Annual Education tax paid by } \\
\text { operating entities }\end{array}$ & $\begin{array}{l}\text { CBN Statistical bulletin, } \\
\text { FIRS }\end{array}$ & - \\
\hline 5. & $\begin{array}{c}\text { Custom and Excise } \\
\text { Duties } \\
\text { (independent } \\
\text { Variable) }\end{array}$ & CEDUT & $\begin{array}{l}\text { Cumulative annual value of } \\
\text { custom and excise duties paid } \\
\text { by companies in Nigeria }\end{array}$ & $\begin{array}{l}\text { CBN Statistical bulletin, } \\
\text { FIRS }\end{array}$ & - \\
\hline 6. & $\begin{array}{c}\text { Official exchange } \\
\text { rate } \\
\text { (independent } \\
\text { Variable) }\end{array}$ & EXRT & $\begin{array}{l}\text { The rate at which Naira } \\
\text { exchanges for U.S. Dollar }\end{array}$ & $\begin{array}{l}\text { World development } \\
\text { indicators of the World } \\
\text { Bank }\end{array}$ & - \\
\hline 7. & $\begin{array}{l}\text { Inflation rate } \\
\text { (independent } \\
\text { Variable) }\end{array}$ & INFL & Consumer price index in Nigeria & $\begin{array}{l}\text { World development } \\
\text { indicators of the World } \\
\text { Bank, }\end{array}$ & - \\
\hline 8. & $\begin{array}{c}\text { Real GDP growth } \\
\text { rate } \\
\text { (independent } \\
\text { Variable) }\end{array}$ & RGDPGR & $\begin{array}{c}\text { Annual growth rate of real } \\
\text { Gross Domestic Products in } \\
\text { Nigeria }\end{array}$ & $\begin{array}{c}\text { World development } \\
\text { indicators of the World } \\
\text { Bank }\end{array}$ & + \\
\hline 9. & Trade Openness & TOPN & The ratio of Net exports & World development & + \\
\hline
\end{tabular}




$\begin{array}{ccc}\text { (independent } & \text { (Exports less Imports) to real } & \text { indicators of the World } \\ \text { Variable) } & \text { Gross Domestic Products in } & \text { Bank }\end{array}$

Table 1 contains the variables used in the study, measurement and how the relevant data relating to the variables were sourced using panel data from 1983 to 2017. We conduct a longitudinal study to assess the impact of the independent variables on FDI. Specifically, the methodology for this study is the error correction model typically used to estimate the speed at which the dependent variable returns to after a change in other variables and widely where the research data have long-run stochastic trend and are cointegrated (Engle, Granger, \& Clive, 1987). The dynamic error correction model is represented in the structural equation below:

$$
\begin{aligned}
. \partial F D I_{t}=\beta_{0}+ & \eta_{i} \sum_{i=0}^{k} . \partial F D I_{t-i}+\psi_{i} \sum_{i=0}^{l} . \partial C I T_{t-i}+\Upsilon_{i} \sum_{i=0}^{m} . \partial V A T_{t-i}+\omega_{i} \sum_{i=0}^{o} . \partial T E T_{t-i} \\
& +\phi_{i} \sum_{i=0}^{p} . \partial C E D U T_{t-i}+\tau_{1}+\xi E C M_{t-1}+u_{t}
\end{aligned}
$$

Where: FDI denotes foreign direct investment, which is the dependent variable; CIT signifies Companies Income Tax; VAT denotes Value-added tax; TET indicates tertiary Education tax; CEDUT represents Custom and excise duties. We segment the variables into two notable dispensations in Nigeria, The military regime from (1983-1998) and the democratic regime from (1999 - 2017). Subscript $t$ indicates the period. Subscript i's denote the number of lags entering the model. $\beta 0$ is the intercept in the model, $\eta \mathrm{i}, \psi \mathrm{t}, ' \Upsilon \mathrm{i}, \alpha_{\mathrm{i}}, \omega_{\mathrm{i}}$, and $\phi_{\mathrm{i}}$ are the parameters in the model. $\mu_{\mathrm{t}}$ is the stochastic disturbance term. ECMt-1 is the error correction term that shows the speed of adjustments of FDI to its long-run stability. $\partial_{\text {Indicates the first difference of }}$ the respective variable which is given as $\mathrm{Xt}-\mathrm{Xt}-1$. Where $\mathrm{Xt}$ could be any variable and $\mathrm{Xt}-1$ is the lagged values of the series under consideration. However, the following restrictions are imposed;

$$
\begin{gathered}
\frac{\partial F D I_{t}}{\partial F D I_{t-1}}=\eta>0, \quad \frac{\partial F D I_{t}}{\partial C I T_{t}}=\psi<0, \quad \frac{\partial F D I_{t}}{\partial V A T_{t}}=\Upsilon<0, \quad \frac{\partial F D I_{t}}{\partial T E T_{t}}=\omega<0, \\
\frac{\partial F D I_{t}}{\partial C E D U T_{t}}=\emptyset<0, \quad \tau_{1}=\tau_{2}=\xi<0, \quad \tau_{3}=\tau_{4}>0 .
\end{gathered}
$$

Therefore, the dynamic error correction model becomes the fundamental equation for this study; and forms the underlying framework on which subsequent estimations, analysis and discussions on the relationship between FDI and the explanatory variables are based. We use the E-Views 11 software to analyze the data.

\section{Result and Discussion}

In this segment, the results of the various findings from the estimations of the military and civilian regimes' models are discussed. The focus here is to look at the differences in performance of corporate taxes in relation to FDI flows into the country during and after the period the military governments were in power. Estimates from the FDI models are presented and discussed accordingly.

\section{Descriptive Statistics}

The descriptive statistics of all the variables employed in this study are reported and analyzed below. The mean, standard deviation, skewness, kurtosis, Jarque-Bera statistics, as well as their resultant probability values are as presented in Table 2. The results reveal that during the military regime the Custom and Excise 
Duty, Company Income Tax, Tertiary Education Tax, Foreign Direct Investment, and Value Added Tax averaged (mean values) N18.47billion, N10.25billion, N2.29billion, N14.46billion, and N8.06billion in that order. Their standard deviation values were reported as N20.38 billion, N12.83 billion, N4.21 billion, N14.7 billion, and N13.80 billion, respectively, during the estimation period. From the table also, The Jarque-Bera statistics and their corresponding probability values indicate that all the variables were normally distributed in the period under review. In addition, Custom and Excise Duty, Company Income Tax, Foreign Direct Investment, and Value Added Tax were found to be platykurtic in their distributions, while Tertiary Education Tax had moderate kurtosis values, indicative of a mesokurtic distribution. Also, all variables were positively skewed in their distributions during the military regime.

The results of the civilian regime, also reported in Table 2 reveal that, Custom and Excise Duty, Company Income Tax, Tertiary Education Tax, Foreign Direct Investment Inflows, and Value Added Tax averaged N257.76 billion, N501.89 billion, N81.46 billion, N697.62 billion, and N384.47 billion respectively. Also, their standard deviation values were reported as N122.12 billion, N396.21 billion, N81.03 billion, N422.84 billion, and N281.86 billion, respectively, during the civilian regime. All the series employed in this study were normally distributed in the period under review. In addition, all the series were found to be platykurtic in their distributions, while also maintaining positive skewedness.

Table 2. Descriptive statistics of variables

\begin{tabular}{|c|c|c|c|c|c|}
\hline \multicolumn{6}{|c|}{ Military Regime } \\
\hline statistic & $\begin{array}{l}\text { Custom And } \\
\text { Excise Duty }\end{array}$ & $\begin{array}{c}\text { Company } \\
\text { Income Tax }\end{array}$ & $\begin{array}{c}\text { Tertiary } \\
\text { Education Tax }\end{array}$ & $\begin{array}{c}\text { Foreign Direct } \\
\text { Investment }\end{array}$ & $\begin{array}{c}\text { Value } \\
\text { Added Tax }\end{array}$ \\
\hline Mean & 18.47 & 10.25 & 2.29 & 14.65 & 8.06 \\
\hline Std. Dev. & 20.38 & 12.83 & 4.21 & 14.7 & 13.8 \\
\hline Skewness & 1.06 & 1.13 & 1.33 & 0.55 & 1.25 \\
\hline Kurtosis & 2.52 & 2.65 & 3 & 1.87 & 2.77 \\
\hline Jarque-Bera & 3.13 & 3.46 & 4.72 & 1.64 & 4.18 \\
\hline Probability & 0.21 & 0.18 & 0.09 & 0.44 & 0.12 \\
\hline Obs & 16 & 16 & 16 & 16 & 16 \\
\hline \multicolumn{6}{|c|}{ Civilian Regime } \\
\hline Mean & 257.76 & 501.89 & 81.46 & 697.62 & 384.47 \\
\hline Std. Dev. & 122.12 & 396.21 & 81.03 & 422.84 & 281.86 \\
\hline Skewness & 0.02 & 0.47 & 0.88 & -0.01 & 0.24 \\
\hline Kurtosis & 2.3 & 1.89 & 2.79 & 1.79 & 1.54 \\
\hline Jarque-Bera & 0.39 & 1.67 & 2.49 & 1.15 & 1.88 \\
\hline Probability & 0.82 & 0.43 & 0.29 & 0.56 & 0.39 \\
\hline Obs & 19 & 19 & 19 & 19 & 19 \\
\hline
\end{tabular}

Source: Author's Computation using E-views 11

\section{Testing for Stationarity}

Granger and Newbold (1977) and Hall, Lazarova and Urga (1999) posit that a sizeable number of time series variables do not often behave in a stationary manner over time. Consequently, the risks embedded in the utilization of such data in regression assessments are well explicated in the production of estimates that are spurious in nature and thus, cannot be considered for policy analysis. Table 3 presents the results of the stationarity tests using both the Augmented Dickey-Fuller and Phillip-Perron tests of the time series employed in panel A, through panel D for both the military and civilian regime below. The result shows that all the variables under consideration were stationary at first difference in both test results. Similarly, all the series were found to be stationary at $1.0 \%$ significance level in both the Augmented Dickey-Fuller and Phillip-Perron test results. This further validates the choice of the ECM technique. The stationarity tests results for both regimes are summarized in Table 3 below. 
Table 3. Stationarity tests-Augmented Dickey-Fuller and Phillip-Perron tests approaches

\begin{tabular}{|c|c|c|c|c|c|c|c|}
\hline \multicolumn{4}{|c|}{ Military Regime (1983-1998) } & \multicolumn{4}{|c|}{ Civilian Regime (1999-2017) } \\
\hline Variables & $\begin{array}{c}\text { Test } \\
\text { statistic }\end{array}$ & $\begin{array}{c}1 \% \\
\text { Critical } \\
\text { values }\end{array}$ & Remarks & Variables & $\begin{array}{c}\text { Test } \\
\text { statistic }\end{array}$ & $\begin{array}{c}1 \% \text { Critical } \\
\text { values }\end{array}$ & Remarks \\
\hline \multicolumn{4}{|c|}{ Panel A. Augmented Dickey-Fuller Tests Results } & \multicolumn{4}{|c|}{ Panel C. Augmented Dickey-Fuller Tests Results } \\
\hline $\mathrm{D}(\mathrm{CEDUT})$ & -4.95 & -4.67 & $\mathrm{I}(1) * * *$ & $\mathrm{D}(\mathrm{CEDUT})$ & -4.67 & -2.71 & $\mathrm{I}(1)^{* * *}$ \\
\hline $\mathrm{D}(\mathrm{CIT})$ & -4.05 & -3.92 & $\mathrm{I}(1)^{* * *}$ & $\mathrm{D}(\mathrm{CIT})$ & -4.25 & -3.96 & $\mathrm{I}(1)^{* * *}$ \\
\hline $\mathrm{D}(\mathrm{TET})$ & -3.84 & -2.72 & $\mathrm{I}(1) * * *$ & $\mathrm{D}(\mathrm{TET})$ & -4.3 & -3.92 & $\mathrm{I}(1) * * *$ \\
\hline $\mathrm{D}(\mathrm{EXRT})$ & -3.5 & -2.73 & $\mathrm{I}(1)^{* * *}$ & $\mathrm{D}(\mathrm{FDI})$ & -6.12 & -3.89 & $\mathrm{I}(1) * * *$ \\
\hline $\mathrm{D}(\mathrm{FDI})$ & -3.29 & -2.71 & $\mathrm{I}(1)^{* * *}$ & $\mathrm{D}(\mathrm{VAT})$ & -5.22 & -3.89 & $\mathrm{I}(1)^{* * *}$ \\
\hline \multicolumn{4}{|c|}{ Panel B. Phillips-Perron Tests Results } & \multicolumn{4}{|c|}{ Panel D. Phillips-Perron Tests Results } \\
\hline $\mathrm{D}(\mathrm{CEDUT})$ & -3.99 & -4.62 & $\mathrm{I}(1)^{* * *}$ & $\mathrm{D}(\mathrm{CEDUT})$ & -4.64 & -2.71 & $\mathrm{I}(1)^{* * *}$ \\
\hline $\mathrm{D}(\mathrm{CIT})$ & -4.21 & -3.92 & $\mathrm{I}(1)^{* * *}$ & $\mathrm{D}(\mathrm{CIT})$ & -6.22 & -2.71 & $\mathrm{I}(1)^{* * * *}$ \\
\hline $\mathrm{D}(\mathrm{TET})$ & -3.26 & -2.72 & $\mathrm{I}(1)^{* * *}$ & $\mathrm{D}(\mathrm{TET})$ & -4.59 & -3.89 & $\mathrm{I}(1) * * *$ \\
\hline $\mathrm{D}(\mathrm{EXRT})$ & -3.26 & -2.72 & $\mathrm{I}(1)^{* * *}$ & $\mathrm{D}(\mathrm{FDI})$ & -6.16 & -3.89 & $\mathrm{I}(1)^{* * *}$ \\
\hline $\mathrm{D}(\mathrm{FDI})$ & -3.73 & -2.71 & $\mathrm{I}(1)^{* * *}$ & $\mathrm{D}(\mathrm{VAT})$ & -5.56 & -3.89 & $\mathrm{I}(1) * * *$ \\
\hline
\end{tabular}

NB: ***Significant at 1 percent.

Source: Author's Computation using E-views 11

Testing for Co-Integration

Cointegration tests are generally carried out to determine the presence of long-run relationship among the variables in a Regression equation. This study adopts the procedure advanced by Johansen (1988) as well as Johansen and Juselius (1990). By using the approach presented by Johansen and Juselius (1990), the MaxEigen and Trace statistic are utilized in evaluating the number of possible cointegrating vectors. The cointegration results reveal proof of cointegrating relationships as displayed by the significance of the Fisher statistics from Trace test and that from Max-Eigen test results presented in Table 4. Explicitly, both Trace test and the Max-eigenvalue test indicate 3 cointegrating equations at both 5 per cent and $1.0 \%$ levels respectively, for both the military and civilian regime. It therefore follows that the variables entering the error correction model for the civilian regime estimations are; Custom and Excise Duty, Company Income Tax, Tertiary Education Tax, Foreign Direct Investment and Value Added Tax. This enables us to make uniform comparison between the two dispensations on which various empirical analyses were carried out.

Table 4. Cointegration test results: Trace and Max-Eigenvalue approaches

Series: FDI CIT VAT TET CEDUT

Lags interval (in first differences): 1 to 1

\begin{tabular}{|c|c|c|c|c|c|c|c|c|c|}
\hline \multicolumn{5}{|c|}{ 1983-1998 } & \multicolumn{5}{|c|}{ 1999-2017 } \\
\hline \multicolumn{2}{|c|}{ Hypotheses } & \multirow{2}{*}{$\begin{array}{c}\text { Test } \\
\text { statistic } \\
\mathbf{p}=\mathbf{1 0}\end{array}$} & \multicolumn{2}{|c|}{ Critical values } & \multicolumn{2}{|c|}{ Hypotheses } & \multirow{2}{*}{$\begin{array}{c}\text { Test } \\
\text { statistic } \\
\mathbf{p}=\mathbf{1 0}\end{array}$} & \multicolumn{2}{|c|}{ Critical values } \\
\hline $\begin{array}{c}\text { Null } \\
\text { Hypothesi } \\
\text { s }\end{array}$ & $\begin{array}{c}\text { Alternativ } \\
\text { e }\end{array}$ & & $\begin{array}{l}\text { 5per } \\
\text { cent }\end{array}$ & $\begin{array}{l}1 \text { per } \\
\text { cent }\end{array}$ & $\begin{array}{c}\text { Null } \\
\text { Hypothesis }\end{array}$ & $\begin{array}{c}\text { Alternativ } \\
\text { e }\end{array}$ & & $\begin{array}{l}\text { 5per } \\
\text { cent }\end{array}$ & $\begin{array}{l}\text { 1per } \\
\text { cent }\end{array}$ \\
\hline \multicolumn{10}{|c|}{ Panel E. $\lambda$ trace-statistic } \\
\hline $\mathrm{H} 0: \mathrm{r}=0$ & $\mathrm{H} 1: \mathrm{r}=1$ & $292.4 * *$ & 87.31 & 96.58 & $\mathrm{H} 0: \mathrm{r}=0$ & $\mathrm{H} 1: \mathrm{r}=1$ & $205.8 * *$ & 87.31 & 96.6 \\
\hline $\mathrm{H} 0: \mathrm{r} \leq 1$ & $\mathrm{H} 1: \mathrm{r}=2$ & $128.3 * *$ & 62.99 & 70.05 & $\mathrm{H} 0: \mathrm{r} \leq 1$ & $\mathrm{H} 1: \mathrm{r}=2$ & $94.23 * *$ & 62.99 & 70.1 \\
\hline
\end{tabular}




\begin{tabular}{|c|c|c|c|c|c|c|c|c|c|}
\hline $\mathrm{H} 0: \mathrm{r} \leq 2$ & $\mathrm{H} 1: \mathrm{r}=3$ & $58.62 * *$ & 42.44 & 48.45 & $\mathrm{H} 0: \mathrm{r} \leq 2$ & $\mathrm{H} 1: \mathrm{r}=3$ & $53.27 * *$ & 42.44 & 48.5 \\
\hline $\mathrm{H} 0: \mathrm{r} \leq 3$ & $\mathrm{H} 1: \mathrm{r}=4$ & 17.98 & 25.32 & 30.45 & $\mathrm{H} 0: \mathrm{r} \leq 3$ & $\mathrm{H} 1: \mathrm{r}=4$ & 19.76 & 25.32 & 30.5 \\
\hline $\mathrm{H} 0: \mathrm{r} \leq 4$ & $\mathrm{H} 1: \mathrm{r}=5$ & 5.09 & 12.25 & 16.26 & $\mathrm{H} 0: \mathrm{r} \leq 4$ & $\mathrm{H} 1: \mathrm{r}=5$ & 4.71 & 12.25 & 16.3 \\
\hline \multicolumn{10}{|c|}{ Panel F. $\lambda$ max-statistic } \\
\hline $\mathrm{H} 0: r=0$ & $\mathrm{H} 1: \mathrm{r}=1$ & $164.0^{* *}$ & 37.52 & 42.36 & H0: $r=0$ & $\mathrm{H} 1: \mathrm{r}=1$ & $111.6^{* *}$ & 37.52 & 42.4 \\
\hline $\mathrm{H} 0: \mathrm{r} \leq 1$ & $\mathrm{H} 1: \mathrm{r}=2$ & $69.69 * *$ & 31.46 & 36.65 & $\mathrm{H} 0: \mathrm{r} \leq 1$ & $\mathrm{H} 1: \mathrm{r}=2$ & $40.96 * *$ & 31.46 & 36.7 \\
\hline $\mathrm{H} 0: \mathrm{r} \leq 2$ & $\mathrm{H} 1: \mathrm{r}=3$ & $40.63^{* *}$ & 25.54 & 30.34 & $\mathrm{H} 0: \mathrm{r} \leq 2$ & $\mathrm{H} 1: \mathrm{r}=3$ & $33.51 * *$ & 25.54 & 30.3 \\
\hline $\mathrm{H} 0: \mathrm{r} \leq 3$ & $\mathrm{H} 1: \mathrm{r}=4$ & 12.90 & 18.96 & 23.65 & $\mathrm{H} 0: \mathrm{r} \leq 3$ & $\mathrm{H} 1: \mathrm{r}=4$ & 15.06 & 18.96 & 23.7 \\
\hline $\mathrm{H} 0: \mathrm{r} \leq 4$ & $\mathrm{H} 1: \mathrm{r}=5$ & 5.09 & 12.25 & 16.26 & $\mathrm{H} 0: \mathrm{r} \leq 4$ & $\mathrm{H} 1: \mathrm{r}=5$ & 4.71 & 12.25 & 16.3 \\
\hline \multicolumn{10}{|c|}{ Trend assumption: Linear deterministic trend (restricted) } \\
\hline
\end{tabular}

Source: Author's Computation using E-views 11

\section{Parsimonious Error Correction Estimates}

The general objective of evaluating the impact of Corporate Taxes (Custom and Excise Duty, Company Income Tax, Tertiary Education Tax and Value Added Tax) on Foreign Direct Investment in Nigeria was accomplished with the aid of the Error Correction Modeling approach (ECM). Having ascertained that the variables are stationary at first difference and cointegrated, an error correction technique is adopted in order to capture the short-run dynamics that might have resulted in the course of estimating the long-run cointegrating series. In this regard, the error correction factor enables us to determine the speed of adjustment of FDI in Nigeria to its long-run convergence (stability). The result of the error correction model estimation in Table 5 revealed that previous year innovations in foreign direct investments have positive relationship with its current level. Also, it was found to be statistically significant at 10 percent level during the military regime. In addition, the result indicates that about 0.46 unit and 0.06unit expansion in the current level of foreign direct investments inflows was due to a unit rise in its one-period lagged values in the military and civilian regime respectively.

However, a negative linkage was observed between Company Income Tax and FDI at 1 percent and 5 percent significance levels in the military and civilian regime respectively. The same was true in the case of previous year innovations in Company Income Tax in relation to FDI as observed in the civilian administration. This result substantiates earlier finding of Saidu (2015); Olaleye, Riro and Memba (2016); Raudonen (2016); Davies, Siedschlag and Studnicka (2017); Akinwunmi, Olotu and Adegbie (2017); Eiya and Okaiwele (2019). Evidently, the result implies that, a rise in Company Income Tax by one unit ceteris paribus, will bring about a corresponding decline in the level of Foreign Direct Investments in the country by about 3.79 units and 0.67 unit in the military and civilian regime respectively. Furthermore, the coefficients of Value Added Tax (-0.31 and -1.71) reveal a negative and statistically significant relationship (at 1 percent and 5 percent significance levels) between Value Added Tax and Foreign Direct Investments in the military and civilian dispensations respectively. This is in consonance with the previous finding of Eiya and Okaiwele (2019). Specifically, the result indicates that, 1 unit fall in Value Added Tax ceteris paribus; will occasion a proportionate improvement in Foreign Direct Investments by 0.31 unit and 1.71 units respectively.

Conversely, the result, though, contrary to the apriori expectation, suggests a statistically significant positive relationship in the military regime (at 1 percent significance level) between Tertiary Education Tax and Foreign Direct Investments. Explicitly, the result shows that, about 0.37unit and 0.84unit rise in the country's Foreign Direct Investments is ascribed to 1 unit rise in Tertiary Education Tax in both the military and civilian regime respectively. Also, the coefficients of Custom and Excise Duty (-1.24 and -0.70) indicate that Custom and Excise Duty exerts a statistically significant negative impact (at 10 percent significance 
level) on Foreign Direct Investments in both the military and civilian regime. Interestingly, the result implies that, about 1.24 units and 0.70 unit rise in the country's Foreign Direct Investments is due to 1unit drop in the country's Custom and Excise Duties in the military and civilian regime respectively.

Furthermore, the coefficient of one period lagged error correction term (ECM (-1)) is negative in both regimes. This indicates that, about 79 percent and 66percent of the short-run fluctuations in the foreign direct investments inflows during the military and civilian regime was adjusted every twelve months for the period of estimation respectively, and this is highly significant at 1 percent and 5 percent levels of significance. This is of enormous relevance in the aspect of policy analysis. The coefficients of determination (R2) showed that, about 78 percent and 66 percent of the systematic variations in foreign direct investments are respectively accounted for by the joint influence of all the independent variables utilised in the study, while the remaining 22 percent and 38 percent are due to other series integrated into the error term in the respective modeling frameworks. This further confirms that the models are well fitted. The F-statistic in both models dispels the null hypothesis of mutual inconsequentiality (at 1 percent significance level). In other words, we are about 99 percent confident that the explanatory variables are jointly significant in the both regimes FDI models. From the Error Correction result, the Durbin Watson statistic was 2.21 and 1.98 respectively. This implies the absence of autocorrelation in the estimated models.

Table 5. Parsimonious Error Correction Estimates for both the Military and Civilian Regime

\begin{tabular}{|c|c|c|c|c|c|c|}
\hline \multirow{2}{*}{ Variable } & \multicolumn{3}{|c|}{ 1983-1998 } & \multicolumn{3}{|c|}{ 1999-2017 } \\
\hline & Coef. & t-Stat & Prob. & Coef. & t-Stat & Prob. \\
\hline $\mathrm{C}$ & -0.21 & -0.2 & 0.86 & 40.86 & 1.74 & 0.12 \\
\hline $\mathrm{D}(\mathrm{FDI}(-1))$ & 0.46 & 1.61 & $0.06 * *$ & 0.06 & 0.35 & 0.74 \\
\hline $\mathrm{D}(\mathrm{CIT})$ & -3.79 & -4.04 & $0.00 * * *$ & -0.67 & -2.56 & $0.03 * *$ \\
\hline $\mathrm{D}(\mathrm{CIT}(-1))$ & - & - & - & -0.46 & -5.13 & $0.00 * * *$ \\
\hline $\mathrm{D}(\mathrm{VAT})$ & -0.31 & -4.98 & $0.00 * * *$ & -1.71 & -2.5 & $0.03 * *$ \\
\hline $\mathrm{D}(\mathrm{TET})$ & 0.37 & 4.99 & $0.00 * * *$ & 0.84 & 1.45 & 0.18 \\
\hline $\mathrm{D}(\mathrm{CEDUT})$ & -1.24 & -1.62 & $0.06 *$ & -0.7 & -1.92 & $0.09 *$ \\
\hline $\operatorname{ECM}(-1)$ & -0.79 & -2.22 & $0.01 * * *$ & -0.66 & -2.79 & $0.02 * *$ \\
\hline $\mathrm{R} 2$ & \multicolumn{3}{|c|}{0.78} & \multicolumn{3}{|c|}{0.66} \\
\hline Adjusted R2 & \multicolumn{3}{|c|}{0.66} & \multicolumn{3}{|c|}{0.59} \\
\hline F-statistic & \multicolumn{3}{|c|}{8.92} & \multicolumn{3}{|c|}{4.46} \\
\hline Prob(F-statistic) & \multicolumn{3}{|c|}{0.00} & \multicolumn{3}{|c|}{0.00} \\
\hline Prob(Wald F-stat) & \multicolumn{3}{|c|}{0.00} & \multicolumn{3}{|c|}{0.00} \\
\hline Durbin-Watson stat & \multicolumn{3}{|c|}{2.21} & \multicolumn{3}{|c|}{1.98} \\
\hline Wald F-statistic & \multicolumn{3}{|c|}{1034.54} & \multicolumn{3}{|c|}{739.31} \\
\hline
\end{tabular}

From the Parsimonious Error Correction Estimates for both the Military and Civilian Regime, it was gathered that, FDI model for the military regime exerted more explanatory power (78\%) than that of the civilian administration (66\%) with respect to issues relating to FDI dynamics in Nigeria. Thus, it can be inferred that, tax variables influenced the behavior of FDI more during the military reign than the civilian counterpart. In terms of specific impacts, the effect of CIT on FDI was more substantial during the military regime (-3.79) than in the civilian administration (-0.67). This is also true in the case of CEDUT with coefficient of -1.24 and -0.7 for military and civilian government, respectively. Though, the impacts of VAT and TET were felt more during the civilian regime ( -1.71 and 0.84 respectively) than in the military reign (0.31 and 0.37 , respectively). In addition, FDI had a higher degree of convergence during the military regime (79\%) than that of their civilian counterpart with a convergence speed of $66 \%$, and this is vital for policy assessment. 


\section{Parameter Stability Analysis}

The stability of the properties of the parameter in the models was evaluated with the aid of the plots of the Cumulative Sum of Recursive Residual (CUSUM) in addition to the Cumulative Sum of Squares of Recursive Residual (CUSUMsq). It is worth noting that, while the CUSUM test is appropriate for identifying systematic dynamics in the regression coefficients, the CUSUMsq is used in situations where the deviation from the stability of the regression coefficients is unpredicted. From the graphs presented in figure 1a through 1d, the CUSUM and CUSUM of Squares remained within the 5.0 per cent critical lines throughout the whole periods thus, signifying parameter stability during the course of assessments. The results of the various tests are provided in figures (1a) through (1d) below.

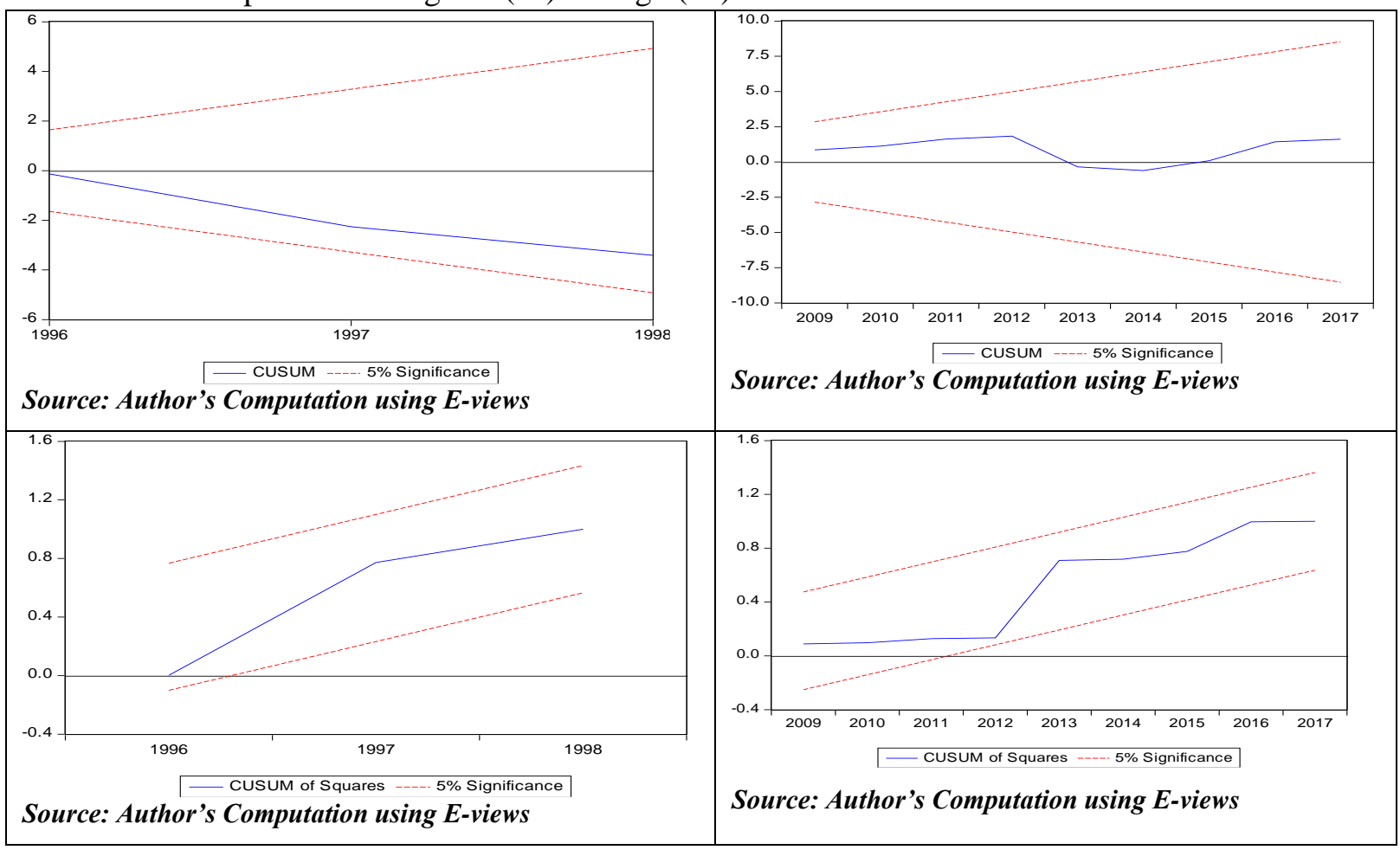

\section{Testing for Pairwise Granger Causality}

In this section, the researchers attempted to ascertain the nature of causality among the pair(s) of variables under consideration. This is achieved by conducting the traditional time series data Granger causality tests in order to augment the quality of estimation procedure as huge amount of degree of freedom is obtained for exactitude. Testing for Granger causality requires the computation of the F-statistics of the Non-Causality hypothesis. Under the null hypothesis of Non-Causality, there is no causal relationship for all the time series pairs. Under the alternative, there is a causal relationship from Xt to Yt series. By utilizing causality tests for the variables employed, the causal links among these variables are considered in detail. This is however considered with a view to fulfilling the objective of the study and further validated earlier findings.

Table 6 reports in detail the F-statistics with their resultant probability values and the projected causality pattern between the variables in the study. The idea is that, the null hypothesis is rejected, when the probability value is less than or equal to 0.10 (suggestive of a statistically significant causality between the pairs of variables of interest at least, at 90 per cent confidence level). Otherwise, we accept the null hypothesis. From the result in Table VI, the following conclusions can be evidently drawn. Bidirectional causality exists between company income tax and foreign direct investment in both regimes, while a unidirectional causality runs from value added tax to FDI during the military regime. However, bidirectional 
causality exists between VAT and FDI during the civilian administration, while bidirectional causality exists between tertiary education tax and FDI during the civilian regime.

In similar finding, a unidirectional causality flows from FDI to customs and exercise duty in both regimes, while VAT granger causes CIT only in the military era. However, a unidirectional causality flows from TET to CIT during the military regime, while the association turned complementary in the case of civilian regime analysis. In what follows, a unidirectional causality flows from CEDUT to CIT during the military regime, while the causation became bidirectional during the civilian regime. Also, a unidirectional causality flows from VAT to TET during the military regime, while the causation became bidirectional during the civilian regime. Nevertheless, a unidirectional causality flows from VAT to CEDUT in both regimes. Finally, a unidirectional causality flows from CEDUT to TET during the military regime, while evidence of complementarity was revealed during the civilian regime.

Table 6. Pairwise Granger causality tests results

\begin{tabular}{|c|c|c|c|c|c|c|}
\hline \multirow{2}{*}{ Null Hypothesis: } & \multicolumn{3}{|c}{ Sample: 1983-1998 } & \multicolumn{3}{c|}{ Sample: 1999-2017 } \\
\cline { 2 - 7 } & Obs. & F-Stat & Prob. & Obs. & F-Stat & Prob. \\
\hline CIT does not Granger Cause FDI & 13 & 3.26 & $0.07^{*}$ & 17 & 3.60 & $0.06^{*}$ \\
\hline FDI does not Granger Cause CIT & & 16.53 & $0.00^{* * *}$ & & 4.08 & $0.04^{* *}$ \\
\hline VAT does not Granger Cause FDI & 13 & 5.79 & $0.02^{* *}$ & 17 & 3.39 & $0.07 *$ \\
\hline FDI does not Granger Cause VAT & & 1.77 & 0.2 & & 6.36 & $0.01^{* * *}$ \\
\hline TET does not Granger Cause FDI & 13 & 1.23 & 0.32 & 17 & 9.65 & $0.00^{* * *}$ \\
\hline FDI does not Granger Cause TET & & 0.9 & 0.42 & & 6.40 & $0.01^{* * *}$ \\
\hline CEDUT does not Granger Cause FDI & 13 & 0.91 & 0.42 & 17 & 0.09 & 0.92 \\
\hline FDI does not Granger Cause CEDUT & & 6.6 & $0.01^{* * *}$ & & 6.35 & $0.01^{* * *}$ \\
\hline VAT does not Granger Cause CIT & 13 & 33.89 & $0.00^{* * *}$ & 17 & 1.99 & 0.18 \\
\hline CIT does not Granger Cause VAT & & 0.7 & 0.51 & & 2.33 & 0.14 \\
\hline TET does not Granger Cause CIT & 13 & 13.44 & $0.00^{* * *}$ & 17 & 10.62 & $0.00^{* * *}$ \\
\hline CIT does not Granger Cause TET & & 1.13 & 0.35 & & 4.38 & $0.04 * *$ \\
\hline CEDUT does not Granger Cause CIT & 13 & 22.75 & $0.00^{* * *}$ & 17 & 3.47 & $0.06^{*}$ \\
\hline CIT does not Granger Cause CEDUT & & 0.94 & 0.41 & & 5.98 & $0.02^{* *}$ \\
\hline TET does not Granger Cause VAT & 13 & 0.19 & 0.81 & 17 & 9.91 & $0.00^{* * *}$ \\
\hline VAT does not Granger Cause TET & & 20.88 & $0.00^{* * *}$ & & 8.85 & $0.00^{* * *}$ \\
\hline CEDUT does not Granger Cause VAT & 13 & 1.34 & 0.29 & 17 & 1.95 & 0.18 \\
\hline VAT does not Granger Cause CEDUT & & 3.44 & $0.06^{*}$ & & 17.06 & $0.00^{* * *}$ \\
\hline CEDUT does not Granger Cause TET & 13 & 3.54 & $0.06^{*}$ & 17 & 5.82 & $0.02^{* *}$ \\
\hline TET does not Granger Cause CEDUT & & 1.05 & 0.37 & & 5.82 & $0.02^{* *}$ \\
\hline
\end{tabular}

Further comparative assessment of the Nigeria data obtained from the statistical report of the World Bank (2018) reveals that, foreign direct investment inflows to the country was relatively higher during the civilian regime. For instance, the military regime occasioned an average of N14.65billion in FDI, while during the civilian regime, the FDI inflows to the country averaged N697.62 billion. Similarly, maximum of N42.89 billion worth of FDI inflows was recorded during the military reign, while the maximum volume recorded during the civilian administration was $\mathrm{N} 1,360.29$ billion. It was further ascertained that a minimum of N0.14billion and N93.15billion worth of FDI flown into the country during the military and civilian regime respectively. In general, Nigeria recorded the sum of $\mathrm{N} 234.39$ billion in FDI during the military administration, while a total of N13, 254.72 billion worth of FDI was received in the country in the course of the civilian dispensation.

Some of the adduced reasons for the sharp variations in the figures between the two regimes can be due to the following submissions; first, the military regime lasted for a period of 16 years (1983-1998), while the civilian administration covered an assessment period of 19 years (1999-2017). Thus, the difference of 3years 
could have meant a lot to the nation in the area of FDI inflows. Another notable reason for the significant periodic differentials in FDI inflows into the country bordered on the sharp, inhuman, antidemocratic, insensitive and incoherent practices of the military dictators which frustrated the efforts of foreign investors. Such unpatriotic acts range from unwarranted tax drain, frequent oppression of civilians by the military, poor legal framework of foreign investments, among other factors, which perpetually allayed fear and colossal loss of confidence on the part of both existing and prospective foreign investors during the military dictatorship.

Furthermore, the poor level of international relations in Nigeria was another notable cause of the weak FDI inflow during the military regime. For instance, Nigeria's foreign relations were at the lowest ebb between 1983 and 1987. Thus, there were no concrete efforts at occasioning foreign investments into the country during the said regime. The country had also improved in recent years in terms of ease of doing business ranking (from 147th in 2013 down to 145th in 2017). Figure 2 compares the foreign direct investment flows in Nigeria under the two dispensations.

\begin{tabular}{|c|c|c|}
\hline Statistic & Military regime & Civilian regime \\
\hline Mean & 14.65 & 697.62 \\
\hline Maximum (Billion) & 42.89 & 1360.29 \\
\hline Minimum (Billion) & 0.14 & 93.15 \\
\hline Sum (Billion) & 234.39 & 13254.72 \\
\hline Observations & 16 & 19 \\
\hline
\end{tabular}

Figure IV. Foreign Direct Investment in Nigeria

\section{Conclusion}

This study compared the effect of corporate taxes on foreign direct investments during the military regime and civilian rule in Nigeria between 1983 and 2017. Military regimes have been known to have stringent tax policies that hamper investments and the flow of capital. Theoretically, the direction of investment is driven by tax policies unless fiscal policies are put in place to ameliorate the impact of tax policies on investments and the provision of goods and services. The extant literature on this topic has produced mixed results on the effect of taxes on the direction of FDI.

Our research findings corroborated previous findings on the association between corporate taxes on FDI. The evidence in this paper shows that military regime exerted more explanatory power of $79 \%$ than that of the civilian administration of $66 \%$ with respect to the impact of corporate taxes on FDI dynamics. The implication being that the military regime executed fiscal policies that reduced the flow of foreign direct investments in Nigeria. Also, the effect of company income tax on FDI was more pronounced during the military regime than in the civilian regime. This evidence is true because the aggregate inflow of foreign direct investments during the civilian rule was higher than the military regime which corroborates the findings of this study.

The approach applied in this study is a significant improvement on methodologies used in previous studies such as the OLS and other traditional techniques. The ECM methodology captures both the short run and long run specifications. The only limitation to this approach is that it does not cater for the interaction among the variables in the model. Similarly, because the data used were transformed to their First Difference, this may lead to possible loss of information about the original data generated from the principal sources. Therefore, a combination of the ECM and OLS might help in this regard given that the variables were stationary at some levels. Future researchers may want to explore this methodology and the inclusion of other tax variables not covered in the study. 


\section{References}

Adegbite, T. A., \& Akande, S. S. (2015). The analysis of the impact of corporate income tax on investment in Nigeria. Wo rld Wi d eJ ournalof M ultidisci pl inary R esearchand D evelop me nt.

Akinleye, G. T., Olarewaju, O. M., \& Fajuyagbe, S. B. (2019). Assessing the Effects of Corporate Taxation on the Investment Policy of Manufacturing Firms in Nigeria. Folia Oeconomica Stetinensia, 19(2), 7-24. http://doi:10.2478/foli-2019-0010

Jelil, A. A., Eunice, O. A., \& Festus, A. F. (2017). Multiplicity of Taxes and Foreign Direct Investment: A Relational Analysis of Nigerian Tax Environment. Social Sciences, 6(4), 91-101. http://doi:10.11648/j.ss.20170604.11

Anyanwu, J. C., \& Yameogo, N. D. (2015). What drives foreign direct investments into West Africa? An empirical investigation. African Development Review, 27(3), 199-215.http://doi:10.1111/1467-8268.12141

Anyiwe, M. A., \& Oziegbe, A. (2006). Democracy and economic growth: Statistical evidence from Nigeria 1960-2002. Journal of Applied Sciences, 6(2), 257-265.http://doi:10.3923/jas.2006.257.265

Arawomo, O., \& Apanisile, J. F. (2018). Determinants of foreign direct investment in the Nigerian telecommunication sector. Modern Economy, 9(05), 907. http://doi:10.4236/me.2018.95058

Babatope, B. (2020, January 22). Of Nigeria's dying factories and exodus to Ghana. Retrieved from: https://punchng.com/of-nigerias-dying-factories-and-exodus-to-ghana/

Boly, A., Coulibaly, S., \& Kéré, E. N. (2020). Tax Policy, Foreign Direct Investment and Spillover Effects in Africa. Journal of African Economies, 29(3), 306-331. http://doi:10.1093/jae/ejz032

Chenaf-Nicet, D., \& Rougier, E. (2016). The effect of macroeconomic instability on FDI flows: A gravity estimation of the impact of regional integration in the case of Euro-Mediterranean agreements. International Economics, 145, 6691.http://doi:10.1016/j.inteco.2015.10.002

Meyer, D. F., \& Habanabakize, T. (2018). An analysis of the relationship between foreign direct investment (FDI), political risk and economic growth in South Africa. Business and Economic Horizons (BEH), 14(1232-2019-870), 777788. http://dx.doi.org/10.15208/beh.2018.54

Davies, R. B., Siedschlag, I., \& Studnicka, Z. (2016). Corporate Taxation and Foreign Direct Investment in EU Countries: Policy Implications for Ireland. ESRI Quarterly Economic Commentary.

Dinh, T. T. H., Vo, D. H., \& Nguyen, T. C. (2019). Foreign direct investment and economic growth in the short run and long run: Empirical evidence from developing countries. Journal of Risk and Financial Management, 12(4), 176.http://doi:10.3390/jrfm12040176

Dunning, J. H., \& Lundan, S. M. (2008). Multinational enterprises and the global economy. Edward Elgar Publishing. Ebekozien, A., Abdul-Aziz, A. R., \& Jaafar, M. (2018). A comparative study of foreign direct investment in Nigerian construction sector during military regime and democratic government from 1984 to 2017. Int Trans J Eng Manage Appl Sci Technol, 9(5), 425-437.

Engle, R. F., \& Granger, C. W. (1987). Co-integration and error correction: representation, estimation, and testing. Econometrica: journal of the Econometric Society, 251-276. https://doi.org/10.2307/1913236

Erhieyovwe, E. K., \& Jimoh, E. S. (2016). Foreign direct investment granger and Nigerian growth. Journal of Innovative Research in Management and Humanities, 3(2). doi:10.3390/jrfm12040176

Etim, R. S., Jeremiah, M. S., \& Jeremiah, O. O. (2019). Attracting Foreign Direct Investment (FDI) In Nigeria through Effective Tax Policy Incentives. International Journal of Applied Economics, Finance and Accounting, 4(2), 36-44. http://doi:10.33094/8.2017.2019.42.36.44

Franklin, A. (2009, July 24). 820 manufacturing companies close down in 9 years- MAN. Retrieved from https://vanguardngr.com/2009/07/820-manufacturing-companies-close-down-in-9-years-man/

Akinleye, G. T., Olarewaju, O. M., \& Fajuyagbe, S. B. (2019). Assessing the Effects of Corporate Taxation on the Investment Policy of Manufacturing Firms in Nigeria. Folia Oeconomica Stetinensia, 19(2), 7 24.http://doi:10.2478/foli-2019-0010

Goldstone, J. A., Bates, R. H., Epstein, D. L., Gurr, T. R., Lustik, M. B., Marshall, M. G., ... \& Woodward, M. (2010). A global model for forecasting political instability. American Journal of Political Science, 54(1), 190-208. https://doi.org/10.1111/j.1540-5907.2009.00426.x

Granger, C. W., Newbold, P., \& Econom, J. (1974). Spurious regressions in econometrics. Baltagi, Badi H. A Companion of Theoretical Econometrics, 557-61. DOI:10.1002/9780470996249 
Hall, S., Lazarova, S., \& Urga, G. (1999). A principal components analysis of common stochastic trends in heterogeneous panel data: Some Monte Carlo evidence. Oxford Bulletin of Economics and Statistics, 61(S1), 749-767. http://doi:10.1111/1468-0084.0610s1749

IMF, O., \& UN, W. (2015). Options for Low Income Countries. Effective and Efficient Use of Tax Incentives for Investment', A Report to the G-20 Development Working Group by the IMF, OECD, UN and World Bank [Online]. Available at: https://www. oecd. org/tax/options-for-low-income-countries-effective-and-efficient-use-of-tax-incenti ves-for-investment. pdf (accessed: 20. 09. 2019). http://doi:10.1596/22924

Johansen, S., \& Juselius, K. (1990). Maximum likelihood estimation and inference on cointegration-with appucations to the demand for money. Oxford Bulletin of Economics and statistics, 52(2), 169-210.

Ebire, K., Onmonya, O., \& Inim, V. E. (2018). Effects of the determinants of foreign direct investment in Nigeria: Error correction mechanism. Asian Journal of Economics and Empirical Research, 5(2), $155-164$. http://doi:10.20448/journal.501.2018.52.155.164

Li, Q., Owen, E., \& Mitchell, A. (2016). Do democracies attract more foreign direct investment? A meta-analysis. In annual meeting of International Political Economy Society, Princeton, NJ. http://dx.doi.org/10.2139/ssrn.3009502 North Douglass, C. (1990). Institutions, institutional change and economic performance. Journal of Women s Health. Ojong, C. M., Arikpo, O. F., \& Ogar, A. (2015). Determinants of foreign direct investment inflow to Nigeria. IOSR Journal of Humanities and Social Science, 20(8), 34-43. DOI: 10.9790/0837-20863443

Olaleye, M. O., Riro, G. K., \& Memba, F. S. (2016). Effect of reduced company income tax incentives on foreign direct investment in listed Nigerian manufacturing companies. http://41.89.227.156:8080/xmlui/handle/123456789/440

Ozekhome, H. O. (2017). Does democratic institutions and foreign direct investment affect economic growth? Evidence from Nigeria. Oradea Journal of Business and Economics, 2(2), 27-36.

Raudonen, S. (2016). Impact of taxation on FDI flows into European Union countries: empirical evidence from a gravity approach. Global Business and Economics Review, 18(3-4), 402-419.http://doi:10.1504/gber.2016.076252

Sabir, S., \& Khan, A. (2018). Impact of political stability and human capital on foreign direct investment in East Asia \& Pacific and south Asian countries. Asian Journal of Economic Modelling, 6(3), 245-256.

DOI: 10.18488/journal.8.2018.63.245.256

Sabir, S., Rafique, A., \& Abbas, K. (2019). Institutions and FDI: evidence from developed and developing countries. Financial Innovation, 5(1), 8. https://doi.org/10.1186/s40854-019-0123-7

Saidu, A. S. (2015). Corporate taxation and foreign direct investment in Nigeria. European Journal of Accounting, Auditing and Finance Research, 3(8), 17-24.

Schoeman, M. (2015). 25th AU Summit: Political Risk and FDI in Africa. South African Institute of International Affairs: Trade Beat, 25.

Tiebout, C. M. (1956). A pure theory of local expenditures. Journal of political economy, 64(5), 416-424. http://doi:10.1086/257839

UNCTAD(2019). Global investment flows flat in 2019, moderate increase expected in 2020. Retrieved from: https://unctad.org/en/pages/newsdetails.aspx?OriginalVersionID=2274

United Nations (2019). Foreign Direct Investment and Sustainable Development in International Investment Governance. Retrieved from: https:/unescap.org/sites/default/files/publications/STII\%20No.90\%20version\%204final.pdf

Van, H. T. (2019). undefined. Proceedings of the Volgograd State University International Scientific Conference "Competitive, Sustainable and Safe Development of the Regional Economy" (CSSDRE 2019). http://doi:10.2991/cssdre-19.2019.58

Zodrow, G. R., \& Mieszkowski, P. (1986). Pigou, Tiebout, property taxation, and the underprovision of local public goods. Journal of Urban Economics, 19(3), 356-370. http://doi:10.1016/0094-1190(86)90048-3 